\section{Potato Tuberworm (Lepidoptera: Gelichiidae) Resistance in Potato Lines with the Bacillus thuringiensis cry1Ac Gene and Natural Resistance}

\author{
Maria A. Estrada, Kelly Zarka, Susannah Cooper, Joseph Coombs, \\ and David S. Douches ${ }^{1}$ \\ Department of Crop and Soil Sciences, Michigan State University, \\ East Lansing, MI 48824
}

Edward J. Grafius

Department of Entomology, Michigan State University, East Lansing, MI 48824

Additional index words. Solanum tuberosum, Phthorimaea operculella, host plant resistance, glycoalkaloids

\begin{abstract}
The potato tuberworm [Phthorimaea operculella (Zeller)] is one of the most destructive insect pests to potato (Solanum tuberosum $\mathbf{L}$.) in tropical and subtropical regions, and it has recently become established in the Pacific Northwest of the United States. Combining natural resistance mechanisms with Bacillus thuringiensis (Bt) cry genes could be a potential solution to improve potato resistance to tuberworm. We have expressed Bt cry1Ac in two potato lines: Spunta, a susceptible potato line, and ND587315, a moderately resistant line with high foliar glycoalkaloids derived from Solanum chacoense. Putative transgenic lines of Spunta and ND5873-15 were developed using a vector construct pSPUD15 with the codon-modified Bt cry1Ac driven by the $35 \mathrm{~S} \mathrm{CaMV}$ promoter. Integration of Bt cry1Ac in Spunta and ND5873-15 transgenic lines was determined by PCR and Southern analysis. Protein expression in the transgenic lines (0-580 $\mathrm{ng}^{-\mathrm{g}^{-1}}$ ) was determined by ELISA. Plants expressing Bt cry1Ac were effective in controlling potato tuberworm first-instar larvae in the detached-leaf bioassays (up to 97\% mortality) and in tuber bioassays (up to $99 \%$ mortality). Based on the assays conducted, the Bt cry1Ac Spunta lines were similar to the Bt cry1Ac ND5873-15 lines for potato tuberworm mortality. Constitutively expressed $B t$ crylAc would be a useful gene to use for host plant resistance to potato tuberworm.
\end{abstract}

Potato (Solanum tuberosum L.) is one of the most important crops for human nutrition worldwide and is a healthy source of carbohydrates, high-quality protein, essential vitamins, minerals, and trace elements (Flanders et al., 1999). It is the highest ranking vegetable crop in production in the United States. Estimated worldwide production is $\approx 330$ million tons per year (FAOSTAT, 2004). In $2005,440,000$ ha were harvested in the United States alone, with a farmgate value of 2.9 billion USD (USDA-NASS, 2005). Potato is vulnerable to insect pests that affect both the foliage and the tuber (Flanders et al., 1999). Both pests and pathogens reduce yields and overall plant vigor. Due to the high economic value of the potato, pesticides are frequently applied to protect this crop.

Potato tuberworm, Phthorimaea operculella (Zeller), is an important and destructive insect pest to the potato worldwide (Flanders et al., 1999). The tuberworm is a common pest in tropical and subtropical regions, and it

Received for publication 5 Dec. 2006. Accepted for publication 29 Mar. 2007.

${ }^{1}$ To whom reprint requests should be addressed; e-mail douchesd@msu.edu
1996). Potatoes contain glycoalkaloids that have long been known to possess antimicrobial properties and insect resistance (Sinden et al., 1980; Tingey, 1984). The two most common glycoalkaloids found in potatoes are $\alpha$-chaconine and $\alpha$-solanine; together they comprise as much as $95 \%$ of the total glycoalkaloid present in the potato (Lachman et al., 2001). In this study, the North Dakota State University breeding line ND5873-15 was used for transformations because it has demonstrated resistance to the Colorado potato beetle in small plot field trials likely due to uncharacterized resistance factors and glycoalkaloids from the wild species Solanum chacoense (Coombs et al., 2005).

Genetic transformation offers considerable potential to improve insect and disease resistance to crops. Potato has been genetically transformed to express genes of various subspecies of Bacillus thuringiensis Berliner (Bt) (Douches and Grafius, 2005). The delta endotoxins of $B$. thuringiensis are the most widely researched genes among the insecticidal enzymes or toxins (Barton and Miller, 1993). The insecticidal crystal proteins produced by $B t$ var. kurstaki are toxins specific toward larvae of Lepidoptera (Chan et al., 1996). Bt toxin genes have been cloned, sequenced, and codon-modified to increase expression level in plants and are now being used in various crop species (Douches and Grafius, 2005). The use of a codon-modified $B t$ gene can provide increased receptor binding and toxicity, broaden the spectrum of activity against target pests, and reduce effects on nontarget insects (Jenkins and Dean, 2001). Jansens et al. (1995) were able to achieve $\approx 100 \%$ potato tuberworm control with expressing the $B t$ crylAb6 in potato tubers. The Bt crylAc9 and cry9Aa2, using the potato light-inducible Lhca3 promoter, offered protection against potato tuberworm larval damage in foliage (Meiyalaghan et al., 2006). Chakrabarti et al. (2006) expressed the Bt cry $9 A a 2$ gene in tobacco chloroplasts and obtained resistance to potato tuberworm, but the high level of expression significantly delayed plant development.

Combining natural host plant resistance and engineered resistance conferred by a $B t$ gene in potato breeding against potato tuberworm may increase the efficacy and stability of resistance (Westedt et al., 1998). Combining different resistance factors assumes the insect is less likely to develop resistance to more than one toxin simultaneously; such strategies can delay resistance by orders of magnitude (Mani, 1985; Roush, 1998; Zhao et al., 2005).

The objectives of this research were to: 1$)$ transform two potato lines that differ in natural host plant resistance (susceptible vs. increased glycoalkaloids) with a codon-modified Bt crylAc gene; 2) conduct molecular characterization of the Bt crylAc transgenic lines to verify gene insertion, determine the number of inserted copies of the gene, and quantify the amount of protein; and 3) assess the potato tuberworm response on Bt crylAc transgenic lines. 


\section{Materials and Methods}

\section{Vector construct.}

The vector pSP 73 crylAc improved, kindly supplied by Dr. John Kemp, New Mexico State University, was digested with XhoI and then treated with T4 DNA polymerase to create blunt ends. It was digested with $B a m \mathrm{HI}$, and the $1.76-\mathrm{kb}$ fragment was isolated. This fragment was ligated to the $11-\mathrm{kb}$ fragment of pBI121, which was cut with BamHI and EcoICRI. The resulting plasmid is pSPUD15 (Fig. 1).

\section{Plant material.}

Two potato lines were used for the Agrobacterium-mediated transformation experiment: Spunta and ND5873-15. Spunta is a long, light-yellow fleshed, tablestock cultivar that was bred in the Netherlands. It is grown widely in subtropical regions, such as North Africa and South America (Douches et al., 2002). ND5873-15 is a breeding line from North Dakota State University (NDSU) that has higher levels of an uncharacterized resistance factor in the foliage derived from the wild relative $S$. chacoense (Dr. J. Lorenzen, pers. comm.). Transgenic lines derived from Spunta and ND5873-15 were named sequentially Sp15.X and ND15.X, respectively.

\section{Transformation protocol.}

Agrobacterium tumefaciens-mediated transformation as described by Douches et al. (1998) and Step I and Step II regeneration media (Yadav and Sticklen, 1995) were used in the generation of the transgenic lines of Spunta and ND5873-15. Potato lines were prepared for transformation by removing the tip and the petiole ends from tissue culture plantlet leaves. All tissue culture and transformation were conducted at room temperature $\left(22 \pm 2{ }^{\circ} \mathrm{C}\right)$ under fluorescent lights on a $16 \mathrm{~h} / 8 \mathrm{~h}$ light/dark schedule. The leaves were then placed top-surface down on the $0.9 \mathrm{mg} \cdot \mathrm{L}^{-1}$ thiamine- $\mathrm{HCl}, 0.5 \mathrm{mg} \cdot \mathrm{L}^{-1}$ transzeatin riboside, $2 \mathrm{mg} \cdot \mathrm{L}^{-1} \quad 2,4-\mathrm{D}, 7 \mathrm{~g} \cdot \mathrm{L}^{-1}$ Bactoagar, $\mathrm{pH}$ 5.7) and precultured for 2-4 d in $10 \times 100 \mathrm{~mm}$ petri dishes (Yadav and Sticklen, 1995). After $2 \mathrm{~d}$, the precultured potato leaves were soaked in the log-phase A. tumefaciens suspension for 5-10 $\mathrm{min}$. solid Step I media (MS salts, 3\% sucrose,

After $4 \mathrm{~d}$, the leaves were then transferred to solid Step II media containing $50 \mathrm{mg} \cdot \mathrm{L}^{-1}$ kanamycin and $200 \mathrm{mg} \cdot \mathrm{L}^{-1}$ Timentin in $10 \times$ $100 \mathrm{~mm}$ petri dishes. Leaves were transferred every 7-10 d to fresh solidified Step II media. Shoots 5-7 mm long were excised and placed in the rooting media (modified MS media with the addition of $50 \mathrm{mg} \cdot \mathrm{L}^{-1}$ kanamycin and $200 \mathrm{mg} \cdot \mathrm{L}^{-1}$ Timentin) in $25 \times 150 \mathrm{~mm}$ culture tubes. One shoot per callus was removed and transferred to the kanamycin rooting media. Rooted shoots were grown in the culture tubes with rooting media and were then transplanted into $3.8 \mathrm{~L}$ pots in the greenhouse for leaf and tuber tissue collection, bioassays and molecular characterization.

\section{Molecular characterization.}

PCR analysis. Presence of the Bt crylAc gene in the transgenic potato lines was determined using PCR. Isolation of total genomic DNA from greenhouse plants was done using the DNeasy Plant Mini method (Qiagen, Valencia, CA). The primers used for the $B t$ crylAc gene were 5' CATGCTATCGAGA CCGGTTACACTCC 3' and 5' CTGTCTA TGATCACACCTGCAGTTCC $3^{\prime}$. The expected band size was $1.8 \mathrm{~kb}$. The PCR amplification conditions were as follows: initial denaturation at $94{ }^{\circ} \mathrm{C}$ for $5 \mathrm{~min}, 30$ cycles of denaturation at $94{ }^{\circ} \mathrm{C}$ for $1 \mathrm{~min}$, annealing at $50{ }^{\circ} \mathrm{C}$ for $1 \mathrm{~min} 30 \mathrm{~s}$, and primer extension at $72{ }^{\circ} \mathrm{C}$ for $1 \mathrm{~min} 30 \mathrm{~s}$, and a final extension at $72{ }^{\circ} \mathrm{C}$ for $4 \mathrm{~min}$. The reactions were held at $4{ }^{\circ} \mathrm{C}$ before the analysis. Reaction products were electrophoresed on a $1 \%(\mathrm{w} / \mathrm{v})$ agarose gel containing ethidium bromide at 0.5 $\mathrm{mg} \cdot \mathrm{mL}^{-1}$ in $1 \times$ Tris-acetate EDTA buffer $(\mathrm{pH} 8.0)$ at $80 \mathrm{mV}$ for $1 \mathrm{~h} 30 \mathrm{~min}$ and viewed under ultraviolet light $(254 \mathrm{~nm})$.

Southern analysis. Integration and copy number of the Bt crylAc gene in the transgenic plants were analyzed by Southern analysis. Total DNA was isolated from the leaf tissue using the CTAB extraction protocol (Saghai-Maroof et al., 1984), modified by adding $2 \% \quad \beta$-mercaptoethanol to the extraction buffer. DNA was digested using $X b a \mathrm{I}$ (Roche, Penzberg, Germany). The digested DNA fragments were then electrophoresed in a $1.2 \%(\mathrm{w} / \mathrm{v})$ agarose gel. The fragments produced in the gel were transferred to a nylon membrane (Hybond $\mathrm{N}^{+}$,

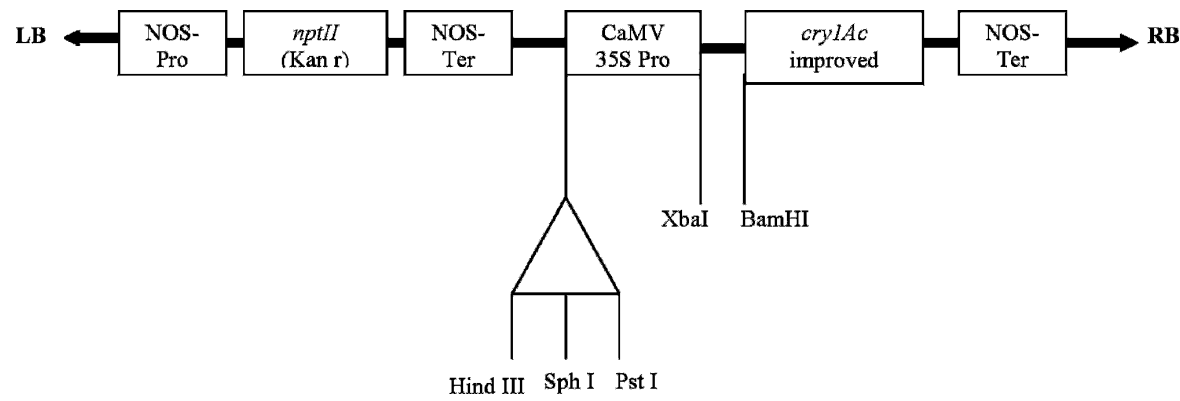

Fig. 1. Schematic diagram of the pSPUD15 vector construct. Abbreviations: RB, right border of T-DNA; NOS-Ter, NOS terminator; crylAc, Bt crylAc insecticidal protein gene; CaMV 35S Pro, promoter; $n p t I I$, neomycin phosphotransferase gene confers resistance to kanamycin; NOS-Pro, NOS promoter; LB, left border of T-DNA.
Amersham Life Sciences, Buckinghamshire, England) via Southern blotting techniques following the manufacturer's procedures. Hybridization was conducted overnight at $42{ }^{\circ} \mathrm{C}$ in a fresh solution containing $\approx 25$ ng. $\mathrm{mL}^{-1}$ DIG-labeled DNA probe. CSPD chemiluminescent detection was conducted following the manufacturer's procedures using $75 \mathrm{mU} \cdot \mathrm{mL}^{-1}$ antidigoxigenin alkalinephosphatase conjugate and $1 \mathrm{~mL}$ of CSPD ready-to-use substrate (Roche, Mannheim, Germany). The membrane was then exposed to X-ray film (Hyperfilm MP, Amersham Life Sciences) for 15-30 min and developed.

ELISA assay. The Bt CrylAc protein expressed in each transgenic plant was detected using the double-antibody sandwich enzyme-linked immunosorbent assay (DAS ELISA) for Bt-Cry1 Ab/1Ac proteins kit from Agdia (Elkhart, IN). Leaf samples were taken from greenhouse-grown plants and were homogenized using Agdia mesh-lined tissue sample bags. The ELISA protocol was done according to the manufacturer's instructions. The optical density was measured using the Wallac Victor II plate reader (PerkinElmer Life Sciences, Downers Grove, IL) at $450 \mathrm{~nm}$. A standard curve was constructed from the controls and was used to compute the $B t$ CrylAc protein expression in $\mathrm{ng} / \mathrm{mL}$.

\section{Potato tuberworm rearing.}

A potato tuberworm population from South Africa has been maintained at the Department of Entomology, Michigan State University, since 2004 on potato tubers following the rearing method described by Mohammed et al. (2000).

\section{Detached-leaf bioassay.}

Fully expanded leaves were collected from greenhouse-grown plants of each potato line. Each petiole was immersed in a water filled vial $(4 \mathrm{~mL})$ sealed with parafilm and placed into a petri dish (125 mm diam.) lined with Whatman No. 2 filter paper (Douches et al., 1998). Ten newly hatched first-instar larvae were placed on each detached-leaf for $3 \mathrm{~d}$ in a no-choice test. The assays were conducted at room temperature $\left(22 \pm 2{ }^{\circ} \mathrm{C}\right)$ under fluorescent lights on a $16 \mathrm{~h} / 8 \mathrm{~h}$ light/ dark schedule. The assays were replicated four times, with each potato line represented in each replicate to compensate for any variance in plant quality between replications. After $3 \mathrm{~d}$, the mortality was measured. Larvae were extracted from the leaf mine under a dissecting microscope and considered dead if no movement was observed after being lightly touched with a small paintbrush. For the high-expressing Bt crylAc lines, ND15.11 and ND15.10, we repeated the experiment with ND5873-15 as a control but extended the duration of the assay to $5 \mathrm{~d}$ to better characterize the resistance reaction for mortality.

\section{Tuber bioassay.}

Tubers were harvested from greenhousegrown plants. A single tuber was placed inside a closed container with vermiculite and 
was exposed to 10 first-instar larvae. Neonates were placed on the tuber eyes with a paintbrush. Each container was considered as a replication. Four replications per transgenic line were used, and the containers were arranged in a completely randomized design in an insect-rearing room $\left(25 \pm 2{ }^{\circ} \mathrm{C}\right.$ and $70 \pm$ $5 \%$ relative humidity). After $21 \mathrm{~d}$, the tubers were cut into sections, the numbers of pupae were recorded, and the overall mortality was expressed as percentage.

\section{Statistical analysis.}

Percentage mortality data for both leaf and tuber bioassays were subjected to arcsine transformation before testing one-way analysis of variance (ANOVA) (SAS Inst., 2001). Means were compared using Fisher's least significant difference (LSD) in the general linear model procedure $(\alpha=0.05)$ of SAS (SAS Inst., Inc., 2001). All results are presented as percent, converted back from the arcsine transformation.

\section{Results}

\section{Potato transformation with Bt cry 1 Ac gene.}

A total of 32 putative transgenic potato shoots were produced from Spunta leaf explants. Of these 32 shoots, 12 rooted in the kanamycin $\left(50 \mathrm{mg} \cdot \mathrm{L}^{-1}\right)$ media. These 12 shoots were then regenerated into plants. Eleven of the 12 rooted plants tested positive for the presence of the Bt crylAc gene via PCR.

ND5873-15 required 8-10 weeks to produce shoots compared with 5-8 weeks for Spunta. A total of 34 putative transgenic potato shoots were regenerated. Of these 34 shoots, 12 rooted in the kanamycin media from ND5873-15. Eight of the 12 rooted shoots were confirmed PCR positive for the presence of the Bt crylAc gene.

\section{Molecular characterization.}

PCR analysis. All the lines that tested PCR positive were subjected to ELISA for protein expression and detached-leaf bioassays. High-performing lines from ND5873-15 and from Spunta were identified from the detached-leaf bioassay (below). These were further characterized using Southern analysis.

Southern analysis. Southern analysis revealed that there was one copy of Bt crylAc inserted in all the lines except for ND15.10 and Sp15.07, which had two copies (Fig. 2).

ELISA assay. Bt Cry1Ac protein expression in Spunta and ND5873-15 transgenic lines varied between 0 to $580 \mathrm{ng} \cdot \mathrm{g}^{-1}$ of fresh leaf tissue (Table 1). In general, the level of protein expression in the ND5873-15 Bt crylAc lines was higher than the level in the Spunta Bt crylAc lines. The controls, Spunta and ND5873-15, tested negative for the Bt Cry1 Ac protein expression.

\section{Detached leaf bioassay.}

The analysis of variance (ANOVA) for the overall model was significant for each of the detached leaf tests and the tuber bio-

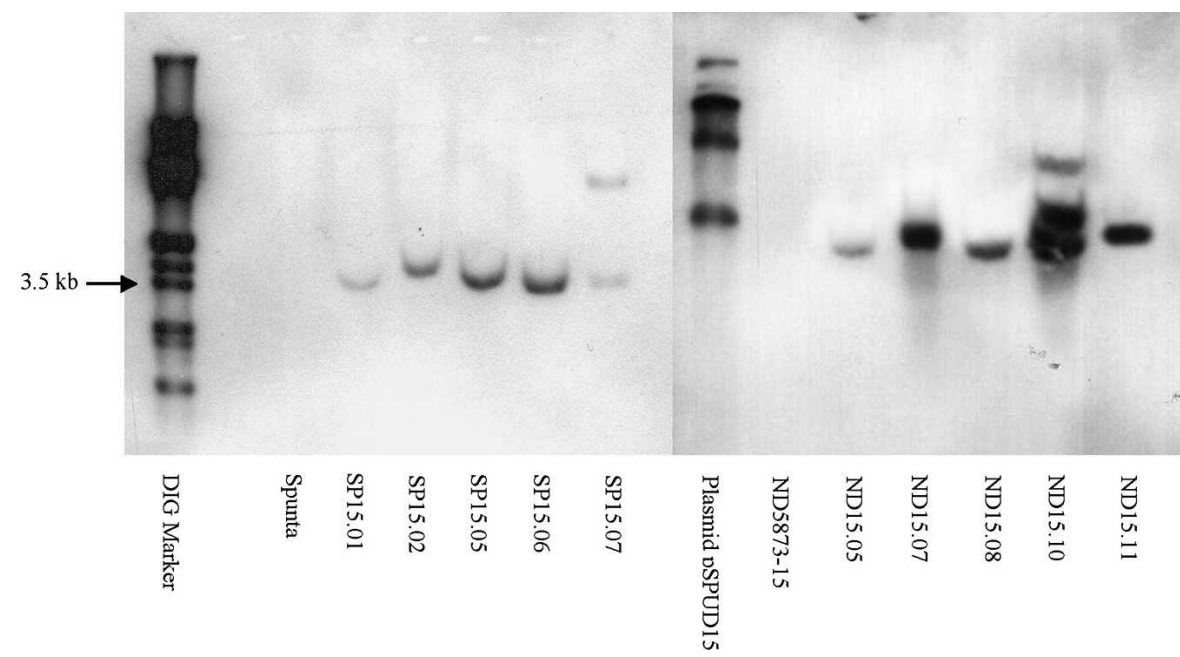

Fig. 2. Southern analysis of ND5873-15 and Spunta Bt crylAc lines to determine the number of gene copies inserted.

assays. The mortality of larvae feeding on non-transgenic Spunta lines (3\%) was significantly lower than the mortality of larvae feeding on any transgenic Spunta line expressing Bt crylAc $(22-58 \% ; P<0.01$; Fig. 3). There was a significant correlation between protein expression and mortality of larvae feeding on transgenic Spunta expressing Bt crylAc $\left(r^{2}=0.40, P=0.02\right)$.

The mortality of larvae feeding on nontransgenic ND5873-15 (35\%) did not differ significantly compared with the mortality of larvae fed on transgenic ND5873-15 lines with lower Bt Cry1 Ac expression, $<100 \mathrm{ng} \cdot \mathrm{g}^{-1}$ of fresh tissue (ND15.01, ND15.05, ND15.08, ND15.12, and ND15.13) $(P<$ 0.01 ) but was significantly higher than Spunta (Fig. 3). In contrast, the mortality of larvae feeding on non-transgenic ND5873-15 was significantly lower than mortality of larvae fed on transgenic ND5873-15 with higher expression, $>100 \mathrm{ng} \cdot \mathrm{g}^{-1}$ of fresh tissue (ND15.07, ND15.10, and ND15.11). Hence, there was a significant correlation between protein expression and mortality of larvae fed on transgenic ND5873-15 expressing $B t$ CrylAc $\left(r^{2}=0.50, P=0.03\right)$.

Comparing ND5873-15 and Spunta $B t$ crylAc transgenic lines with similar expression levels $(<100 \mathrm{ng} / \mathrm{g})$, the mortality of larvae fed on transgenic ND5873-15 lines did not significantly differ from the mortality of larvae fed on transgenic Spunta lines $(P<$ 0.01) (Fig. 3).

In the 5-d detached leaf bioassay evaluation, the mortality of larvae fed on non-transgenic ND5873-15 (17\%) was significantly lower than mortality of larvae fed on transgenic ND15.10 (88\%) and ND15.11 (97\%) $(P<0.01)$ (Fig. 4).

\section{Tuber bioassay.}

Two Bt crylAc-expressing lines (ND15.10 and ND15.11) were selected for the tuber bioassay due to the high levels of control in the leaf bioassay. The mortality of larvae fed on non-transgenic ND5873-15 $(22 \%)$ was significantly lower than mortality
Table 1. Mean Bt Cry1Ac protein expression of Spunta and ND5873-15 Bt crylAc lines. ${ }^{\mathrm{z}}$

\begin{tabular}{lc}
\hline & $\begin{array}{c}\text { Concn of Cry1Ac } \\
\text { protein }(\mathrm{ng} / \mathrm{g} \text { of fresh } \\
\text { leaf tissue) }\end{array}$ \\
Potato line & $\mathbf{0 ~ c}$ \\
ND5873-15 & $50 \mathrm{c}$ \\
ND15.01 & $60 \mathrm{c}$ \\
ND15.05 & $100 \mathrm{c}$ \\
ND15.08 & $40 \mathrm{c}$ \\
ND15.10 & $320 \mathrm{~b}$ \\
ND15.11 & $580 \mathrm{a}$ \\
ND15.12 & $10 \mathrm{c}$ \\
ND15.13 & $10 \mathrm{c}$ \\
Spunta & 0 c \\
Sp15.01 & $20 \mathrm{c}$ \\
Sp15.02 & $80 \mathrm{c}$ \\
Sp15.03 & $30 \mathrm{c}$ \\
Sp15.04 & $0 \mathrm{c}$ \\
Sp15.05 & $60 \mathrm{c}$ \\
Sp15.06 & $40 \mathrm{c}$ \\
Sp15.07 & $50 \mathrm{c}$ \\
Sp15.08 & $0 \mathrm{c}$ \\
Sp15.10 & $0 \mathrm{c}$ \\
Sp15.11 & $10 \mathrm{c}$ \\
Sp15.13 & $0 \mathrm{c}$ \\
\hline
\end{tabular}

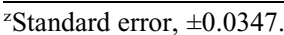

'Mean followed by the same letter are not significantly different, as determined by Fisher's protected LSD $(\alpha=0.05) ; \operatorname{LSD}_{\alpha=0.05}=102 \mathrm{ng} / \mathrm{g}$. Bold entries are non-transgenic.

of larvae fed on transgenic ND15.10 (97\%) and ND15.11 (99\%) $(P<0.01)$ (Fig. 4).

\section{Discussion}

Potato transformation with Bt crylAc using the protocol in our laboratory was effective in regenerating shoots of transgenic potato lines in both Spunta and ND5873-15 lines. The stringency of selection by expressing nptII was effective for Spunta and ND5873-15 and made the number of test samples manageable. Fewer transgenic lines were produced with ND5873-15 than with Spunta, and ND5873-15 lines took longer to produce shoots. Differences in the ease of producing transgenic lines between cultivars were also observed by Felcher et al. (2003). 


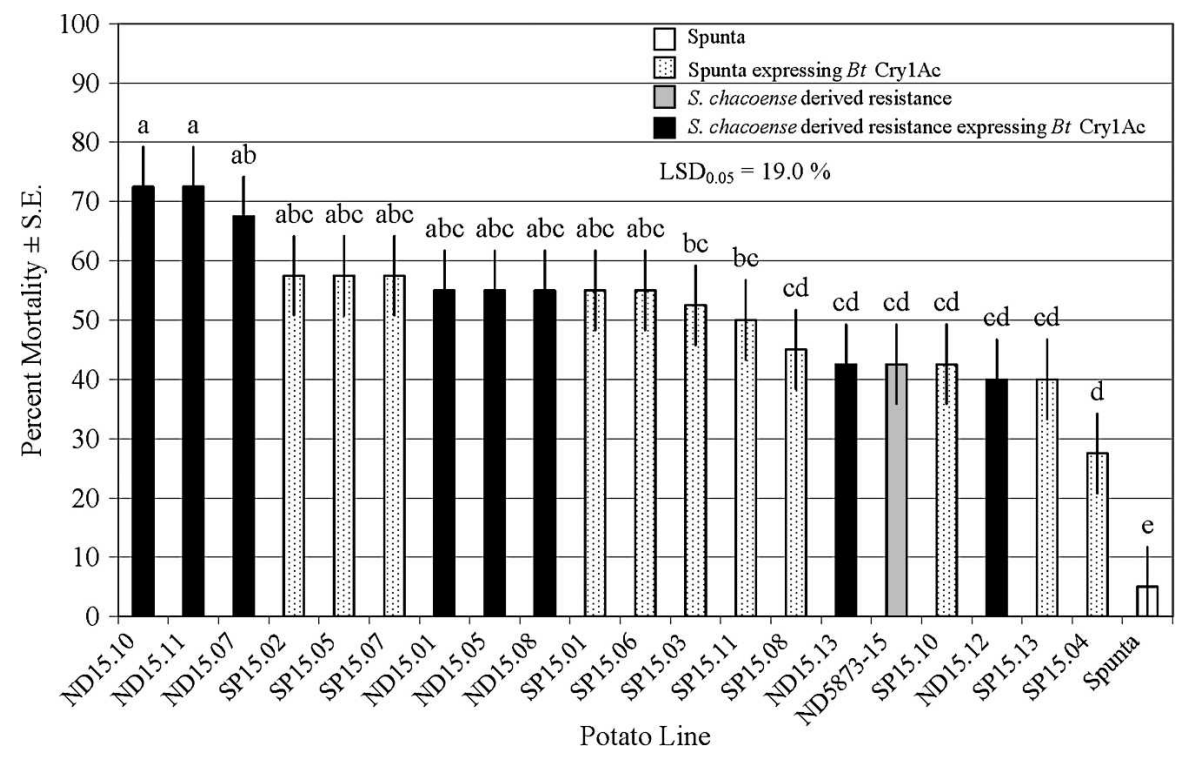

Fig. 3. Mean percent mortality (3-d detached-leaf bioassay) of first instars of potato tuberworm on ND5873-15 and Spunta Bt crylAc lines. Means with the same letter designation (means separated by lowercase letters a, b, c, etc.) are not significantly different, as determined by Fisher's protected LSD $(\alpha=0.05)$.

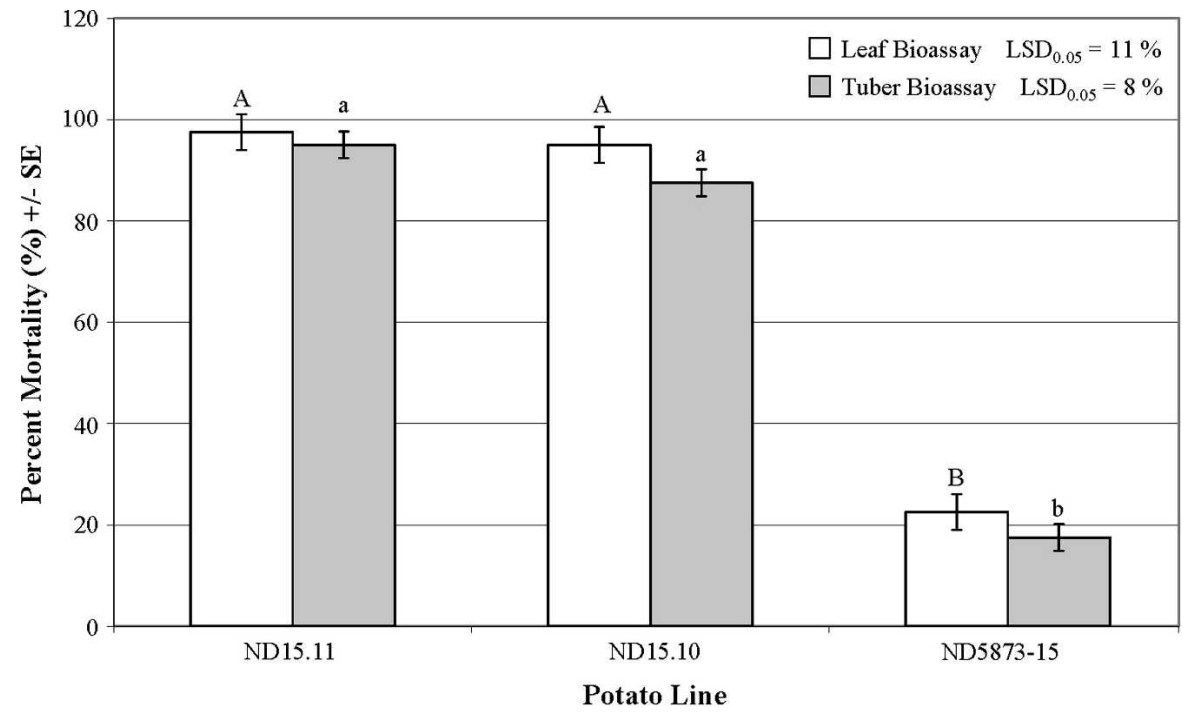

Fig. 4. Mean percent mortality (5-d detached-leaf bioassay and 21-d tuber bioassay) of first instars of potato tuberworm on ND5873-15 (control), ND15.10, and ND15.11. Means with the same letter designation within each bioassay are not significantly different, as determined by Fisher's protected LSD $(\alpha=0.05)$. Detached-leaf bioassay $\operatorname{LSD}_{0.05}=11.3$ (means separated by uppercase letters $\left.\mathrm{A}, \mathrm{B}\right)$. Tuber bioassay $\operatorname{LSD}_{0.05}=8.4$ (means separated by lowercase letters $\mathrm{a}, \mathrm{b}$ ).

In their study, they recovered a significantly higher number of transformed Spunta and Atlantic glucose oxidase transgenic lines compared with Libertas (which gave them few transgenic lines). Similarly, Coombs et al. (2002) transformed three different potato lines, Yukon Gold, USDA8380-1, and NYL235-4, with Bt cry $3 A$ and observed that NYL235-4 produced significantly fewer rooted shoots in the kanamycin $(50 \mathrm{mg} / \mathrm{L})$ medium compared with the other two lines. These differences in the successful regeneration of transgenic shoots between cultivars/ lines suggest that there is genetic variation for regeneration and transformation efficiency.
Southern analysis showed that 1-2 copies of the Bt crylAc gene were inserted in the Spunta and ND5873-15 lines. Similar results were observed by Davidson et al. (2002). They observed that all five of the highest performing transgenic lines had either one or two copies of the Bt crylAc9 gene. Douches et al. (1998) reported one to three copies of Bt crylIal. Copy numbers ranging from one to seven of glucose oxidase gene in transgenic potato lines were observed from the study conducted by Felcher et al. (2003). Similarly, Beuning et al. (2001) also observed one to seven copies of Bt crylAc9 gene inserted in tobacco transgenic lines.
The high mortality of potato tuberworm larvae fed on ND15.11 and ND15.10 corresponded to their high Bt CrylAc protein expression. The ability to achieve high protein expression from both lines may be due to the synthetic codon-modified cry gene used which can give expression that is significantly higher compared with expression of the native cry genes encoding protoxins (Kuvshinov et al., 2001). Native cry genes are expressed poorly in the transgenic plants, thus the resistance to insect pests is minimal (Beuning et al., 2001). Protein expression from cry gene vector constructs are about $0.1 \%$ to $0.3 \%$ of soluble protein corresponding to about $1 \mu \mathrm{g}$ of toxin protein per $1 \mathrm{~g}$ of fresh leaf tissue (Perlak et al., 1993; Kuvshinov et al., 2001). Variation in the level of resistance to potato tuberworm was observed from the independently derived Spunta and ND5873-15 Bt crylAc transgenic lines. Such variation in the level of transgene expression is common among populations of plants that are independently transformed with the same transgenes. In this study, similar mortality was observed for many of the Spunta and ND5873-15 transgenic lines. This could be primarily attributed to the Cry $1 \mathrm{Ac}$ protein levels. This unpredictable expression is usually attributed to position effects resulting from the random integration of transgenes into different sites of plant genomes (Davidson et al., 2002; Conner et al., 1994).

The levels of protein expression obtained from our study (up to $580 \mathrm{ng} \cdot \mathrm{g}^{-1}$ of fresh leaf tissue) were high compared with the protein expression levels observed by Davidson et al. (2002). They observed that the amount of $B t$ CrylAc9 protein in all the transgenic potato lines they tested was $<60 \mathrm{ng} \cdot \mathrm{g}^{-1}$ of fresh leaf tissue. These higher protein levels may have led to greater mortality than was observed by Davidson et al. (2002). Kuvshinov et al. (2001) observed comparable amount of $B t$ Cry9Aa protein expression (300 $\mathrm{ng} \cdot \mathrm{g}^{-1}$ ) in potato plants and higher $B t$ Cry9Aa protein expression (1.4 $\mu \mathrm{g} \cdot \mathrm{g}^{-1}$ of leaf material) in tobacco plant.

There was a significant correlation between mortality in the feeding assay and for protein expression for both ND5873-15 and Spunta Bt crylAc lines. Variability in this correlation lies in the variable responses of the insect larvae and also in the variability inherent in the ELISA determination of protein expression. In a feeding assay, larvae stopped feeding as soon as they became intoxicated. Larvae feeding on potato foliage with low concentrations of $B t$ toxin may have fed longer and consumed more foliage compared with the amount consumed by larvae feeding on foliage with high concentrations of $B t$ toxin.

The resistance provided by the integration of $B t c r y l A c$ in this study was enhanced in both the Spunta and ND5873-15 transgenic lines (Fig. 3); however, the resistance level observed for the best Spunta lines was not different from the best ND5873-15 transgenic lines. In this study, potato tuberworm mortality was similar to the resistance provided 
by the integration of Bt crylIal in the study conducted by Westedt et al. (1998). They observed that potato transformation with a codon-modified Bt cryllal provided up to $96 \%$ mortality of potato tuberworm. In our study, potato tuberworm mortality was up to 97\% (Fig. 4). In their study, Mohammed et al. (2000) observed higher potato tuberworm mortality, up to $100 \%$ in the Bt cryllal Spunta lines, and only partial resistance using a wild-type Bt cry $1 A c$ gene. Similarly, $100 \%$ potato tuberworm mortality after $10 \mathrm{~d}$ was observed with Bt crylAc9 potato lines (Davidson et al., 2002). Jansens et al. (1995) observed protein content of 3-118 ng toxin/mg total protein in the leaves in the Yesmina and Kennebec Bt crylAb lines and $40-100 \%$ potato tuberworm mortality. Davidson et al. (2004) achieved only reduced growth of larvae on potato foliage expressing Bt crylAc9.

The low mortality in ND5873-15 (22\%) in spite of the fact that it has natural resistance may be attributed to the level of glycoalkaloid content in the leaves used in the detached leaf bioassays (Fig. 3). The glycoalkaloid concentration in potato plants can be highly affected by the temperature, light intensity, and daylength. Glycoalkaloids are present at higher concentration in the aerial (leaves, stems, and sprouts) parts of the potato plant and are normally present in lower concentration in the tubers (Lachman et al., 2001). Similarly, Lafta and Lorenzen (2000) observed a significant increase in foliar glycoalkaloids when plants were grown at higher temperatures ( 32 vs. $\left.27{ }^{\circ} \mathrm{C}\right)$. The higher mortality observed in ND5873-15, compared with the Spunta control, is probably the result of the uncharacterized natural insect resistance factors in ND5873-15 (Dr. J. Lorenzen, pers. comm.).

Higher mortality observed in the 5-d detached leaf bioassay with ND15.10 and ND15.11 compared with the mortality on the initial detached leaf bioassay can be attributed to the additional $2 \mathrm{~d}$ of exposure. Longer exposure of the potato tuberworm larvae to the protein/toxins could lead to higher toxin ingestion and higher mortality. Running the detached leaf bioassay for 7-10 d may be optimal. Results from the study conducted by Davidson et al. (2002) suggest that running the detached leaf bioassay for up to $10 \mathrm{~d}$ could give higher potato tuberworm mortality of up to $100 \%$. For the Bt Cry 1 Ac protein to have maximum effect in the Spunta and ND587315 Bt crylAc lines, it may require exposure time of 7-10 d. However, the ability to keep the detached leaves healthy for that period may set practical limits to this assessment.

The production of more independently selected Bt crylAc lines will allow recovery of lines with high transgene expression, as well as phenotypically normal appearance and yield performance (Meiyalaghan et al., 2004). Field and storage trials are also important and necessary tests in the identification of high-performing transgenic potato lines with good transgene expression, phenotypic appearance, and yield equal to that of the commercial cultivars in the market. Further study on the inheritance of Bt crylAc in their progeny is also of value. The $B t$ cryl $1 A c$ gene can be another source of resistance that can be combined with other genes (natural or engineered) for host plant resistance to potato tuberworm in potato.

\section{Literature Cited}

Alvarez, J.M., E. Dotseth, and P. Nolte. 2005. Potato tuberworm: a threat for Idaho potatoes. Univ. Idaho Ext. Bull. CIS1125.

Barton, K.A. and M.J. Miller. 1993. Production of Bacillus thuringiensis insecticidal proteins in plants. Transgen. Plants 1:297-315.

Beuning, L.L., D.S. Mitra, N.P. Markwick, and A.P. Gleave. 2001. Minor modifications to the crylAc9 nucleotide sequence are sufficient to generate transgenic plants resistant to Phthorimaea operculella. Ann. Appl. Biol. 138:281292.

Chan, M., L. Chen, and H. Chang. 1996. Expression of Bacillus thuringiensis (B.t.) insecticidal crystal protein gene in transgenic potato. Bot. Bull. Acad. Sin. 37:17-23.

Chakrabarti, S.K., K.A. Lutz, B. Lertwiriyawong, Z. Svab, and P. Maliga. 2006. Expression of the cry9Aa2 B.t. gene in tobacco chloroplasts confers resistance to potato tuber moth. Transgen. Res. 15:481-488.

Conner, A.J., M.K. Williams, D.J. Abernethy, P.J. Fletcher, and R.A. Genet. 1994. Field performance of transgenic potatoes. N. Z. J. Crop Hort. Sci. 22:361-371.

Coombs, J.J., D.S. Douches, W. Li, E. Grafius, and W. Pett. 2002. Combining engineered (Bt$\operatorname{cry} 3 A$ ) and natural resistance mechanisms in potato for control of Colorado potato beetle. J. Amer. Soc. Hort. Sci. 127(1):62-68.

Coombs, J.J., D.S. Douches, S.G. Cooper, E.J. Grafius, W.L. Pett, and D.D. Moyer. 2005. Combining natural and engineered host plant resistance mechanisms in potato (Solanum tuberosum L.) for Colorado potato beetle (Leptinotarsa decemlineata Say): choice and nochoice field studies. J. Amer. Soc. Hort. Sci. 130(6):857-864.

Davidson, M.M., R.C. Butler, S.D. Wratten, and A.J. Conner. 2004. Resistance of potatoes transgenic for a $c r y l A c 9$ gene, to Phthorimaea operculella (Lepidoptera: Gelechiidae) over field seasons and between plant organs. Assn. Appl. Biol. 145(3):271-277.

Davidson, M., J. Jacobs, J. Reader, R. Butler, C.M. Frater, N.P. Markwick, S.D. Wratten, and A.J. Conner. 2002. Development and evaluation of potatoes transgenic for a $c r y 1 A c 9$ gene conferring resistance to potato tubermoth. J. Amer. Soc. Hort. Sci. 127(4):590-596.

Douches, D.S. and E.J. Grafius. 2005. Transformation for insect resistance, p. 235-266. In: M.K. Razdan and A.K. Mattoo (eds.). Genetic improvement of solanaceous crops, Vol. 1: Potato. Sci. Publ., Inc.

Douches, D.S., W. Li, K. Zarka, J. Coombs, W. Pett, E. Grafius, and T. El-Nasr. 2002. Development of Bt-cry5 insect-resistant potato lines 'Spunta-G2' and 'Spunta-G3'. HortScience 37:1103-1107.

Douches, D.S., A.L. Westedt, K. Zarka, and B. Schroeter. 1998. Potato transformation to combine natural and engineered resistance for controlling tuber moth. HortScience 33(6): 1053-1056.

FAOSTAT. 2004. Food and Agriculture Organization of the United Nations, FAOSTAT data- base. 13 Feb. 2007. <http://faostat.fao.org/site/ 336/default.aspx $>$.

Felcher, K., D. Douches, W. Kirk, R. Hammerschmidt, and W. Li. 2003. Expression of a fungal glucose oxidase gene in three potato cultivars with different susceptibility to late blight (Phytophthora infestans Mont. deBary). J. Amer. Soc. Hort. Sci. 128(2):238-245.

Flanders, K.L., S. Arnone, and E.B. Radcliffe. 1999. The potato: genetic resources and insect resistance, p. 207-239. In: S.L. Clement and S.S. Quisenberry (eds.). Global plant genetic resources for insect-resistance crops. CRC Press, Boca Raton, FL.

Jansens, S., M. Cornellissen, R. De Clerco, A. Reynaerts, and M. Peferoen. 1995. Phthorimaea operculella (Lepidoptera: Gelechiidae) resistance in potato by expression of the Bacillus thuringiensis Cry $1 \mathrm{~A}(\mathrm{~b})$ insecticidal crystal protein. J. Econ. Entomol. 88(5):1469-1476.

Jenkins, J.L. and D.H. Dean. 2001. The complex receptor-binding interactions of insecticidal proteins from Bacillus thuringiensis. BIA J. $8: 25-27$.

Kuvshinov, V., K. Koiva, A. Kanerva, and E. Pehu. 2001. Transgenic crop plants expressing synthetic $\operatorname{cry} 9 \mathrm{Aa}$ gene are protected against insect damage. Plant Sci. 160:341-353.

Lachman, J., K. Hamouz, M. Orsák, and V. Pivec. 2001. Potato glycoalkaloids and their significance in plant protection and human nutrition: a review. Ser. Rostlinná Výroba 47(4):181-191.

Lafta, A.M. and J.H. Lorenzen. 2000. Influence of high temperature and reduced irradiance on glycoalkaloid levels in potato leaves. J. Amer. Soc. Hort. Sci. 125(5):563-566.

Lagnaoui, A., V. Cañedo, and D.S. Douches. 2000. Evaluation of Bt-cryllal (cryV) transgenic potatoes on two species of potato tuber moth, Phthorimaea operculella and Symmetrischema tangolias (Lepidoptera: Gelechiidae) in Peru. CIP Prog. Rpt. 1999-2000:117-121.

Mani, G.S. 1985. Evolution of resistance in the presence of two insecticides. Genetics 109:761-783.

Meiyalaghan, S., M.M. Davidson, M.G.F. Takla, S.D. Wratten, and A.J. Conner. 2004. Effectiveness of four crygenes in transgenic potato for conferring resistance to potato tuber moth. In: T. Fischer, N. Turner, J. Angus, McIntyre L., M. Robertson, A. Borrell, and D. Lloyd (eds.). New directions for a diverse planet. Proc. 4th Int. Crop Sci. Cong., Brisbane, Australia, 26 Sept.-1 Oct. 2004. The Regional Institute Ltd, Gosford, Australia (CD ROM).

Meiyalaghan, S., J.M.E. Jacobs, R.C. Butler, S.D. Wratten, and A.J. Conner. 2006. Expression of cry $1 \mathrm{Ac} 9$ and $c r y 9 \mathrm{Aa} 2$ genes under a potato light-inducible Lhca3 promoter in transgenic potatoes for tuber moth resistance. Euphytica 147:297-309.

Mohammed, A., D.S. Douches, W. Pett, E. Grafius, J. Coombs, Liswidowati, W. Li, and M.A. Madkour. 2000. Evaluation of potato tuber moth (Lepidoptera: Gelechiidae) resistance in tubers of Bt-cry 5 transgenic potato lines. J. Econ. Entomol. 93(2):472-476.

Perlak, F.J., T.B. Stone, Y.M. Muskopf, L.J. Peterson, G.B. Parker, S.A. McPherson, J. Wyman, S. Love, G. Reed, D. Biever, and D.A. Fischhoff. 1993. Genetically improved potatoes: protection from damage by Colorado potato beetle. Plant Mol. Biol. 22(2):313-332.

Roush, R.T. 1998. Two-toxin strategies for management of insecticidal transgenic crops: can pyramiding succeed where pesticide mixtures have not? Philos. Trans. R. Soc. London, Ser. B, Biol. Sci. 353:1777-1786. 
SAS Inst., Inc. 2001. The SAS system for Windows, software release 6.12. SAS Institute, Inc., Cary, NC.

Saghai-Maroof, M.A., K.M. Soliman, R.A. Jorgensen, and R.W. Allard. 1984. Ribosomal DNA spacer-length polymorphisms in barley: Mendelian inheritance, chromosomal location, and population dynamics. Proc. Natl. Acad. Sci. U.S.A. 81:8014-8018.

Sinden, S.L., L.L. Sanford, and S.F. Osman. 1980. Glycoalkaloids and resistance to the Colorado potato beetle in Solanum chacoense Bitter. Am. Potato J. 57:331-343.
Stoner, K.A. 1996. Plant resistance to insects: a resource available for sustainable agriculture. Biol. Agr. Hort. 13(1):7-38.

Tingey, W.M. 1984. Glycoalkaloids as pest resistance factors. Am. Potato J. 61(3):157-167.

USDA-NASS. 2005. U.S. Department of Agriculture National Agricultural Statistics Service. Potatoes, national statistics. 7 Sept. 2006. $<$ http://www.nass.usda.gov:8080/QuickStats/ index2.jsp $>$.

Westedt, A.L., D.S. Douches, W. Pett, and E.J. Grafius. 1998. Evaluation of natural and Engineered resistance mechanisms in Solanum tuberosum for resistance to
Phthorimaea operculella (Lepidoptera: Gelechiidae). J. Econ. Entomol. 91(2): 552-556.

Yadav, N.R. and M. Sticklen. 1995. Direct and efficient plant regeneration from leaf explants of Solanum tuberosum L. cv. Bintje. Plant Cell Rpt. 14:645-647.

Zhao, J.Z., J. Cao, H.L. Collins, S.L. Bates, R.T. Roush, E.D. Earle, and A.M. Shelton. 2005. Concurrent use of transgenic plants expressing a single and two Bacillus thuringiensis genes speeds insect adaptation to pyramided plants. Proc. Natl. Acad. Sci. U.S.A. 102(24):84268430 